\title{
Pengaruh Pemberian Jus Buah Tomat (Solanum lycopersicum) terhadap Kadar Antioksidan pada Ibu Hamil Trimester Ketiga Pascasenam Hamil
}

\section{Abdul Kadir Hasan}

Keperawatan Poltekkes Kemenkes Pangkalpinang

\section{Article Info}

\section{Article History: \\ Accepted May 28 2019}

Key words:

Excersice pregnancy, tomato juice, superoxide dismutase

\section{PENDAHULUAN}

Senam merupakan olah raga terbaik yang dapat dilakukan oleh ibu hamil menjelang persalinannya. Salah satu jenis senam yang ditujukan bagi ibu hamil adalah senam hamil. Senam hamil adalah program kebugaran yang diperuntukkan bagi ibu hamil secara fisik dan mental pada persalinan cepat, aman dan spontan. Senam hamil bertujuan untuk mempersiapkan dan melatih otot-otot sehingga dapat dimanfaatkan untuk berfungsi secara optimal dalam persalinan normal. melalui latihan senam hamil yang teratur dapat dijaga kondisi otot-otot dan persendian yang berperan dalam mekanisme persalinan, mempertinggi kesehatan fisik dan psikis serta kepercayaan pada diri sendiri dan penolong dalam menghadapi persalinan dan membimbing wanita menuju suatu persalinan yang fisiologis. Dengan melakukan senam hamil oksigen yang berlebihan atau tidak termetabolisir dapat digunakan untuk menghasilkan

Corresponding author:

Abdul Kadir Hasan

putrakombathasan@yahoo.co.id

Jurnal Ilmu Keperawatan Maternitas, Vol 2 No 1, May 2019

DOI: http://dx.doi.org/10.26594/jikm.v2.i1.22

e-ISSN 2621-2994 
energi. Pada ibu hamil terdapat 4-5\% oksigen sisa yang tidak termetabolisir menjadi air dan energi. Oksigen sisa ini merupakan sumber utama terjadinya ROS, terutama terbentuknya superoxide, hydroxyl, peroxyl, dan hydroperoxyl anions.

Di satu sisi intensitas maupun kerasnya senam hamil yang dilakukan juga dapat berpengaruh terhadap terbentuknya radikal bebas. Peningkatan radikal bebas ditandai dengan peningkatan marker biokimia malondialdehid (MDA). Adanya radikal bebas yang dihasilkan dalam tubuh sebenarnya merupakan proses fisiologi. Sel-sel menghasilkan sejumlah pertahanan dalam mengatasi hal ini melalui peristiwa yang dikenal dengan counteracting antioxidant defences. Mekanisme pertahanan ini dikelompokkan menjadi scavening radikal bebas dan pemutus rantai reaksi oksidasi (oxidation chain reaction). SOD, Glutation peroksidase (GSHP), dan katalase (CAT) merupakan antioksidan enzimatik pemutus rantai oksidasi sehingga dapat mengurangi radikal bebas pada sel dan mencegah kerusakan akibat oksidasi radikal bebas tersebut.

Mekanisme pertahanan ini dikelompokkan menjadi scavening radikal bebas dan pemutus rantai reaksi oksidasi (oxidation chain reaction). SOD, Glutation peroksidase (GSHP), dan katalase (CAT) merupakan antioksidan enzimatik pemutus rantai oksidasi sehingga dapat mengurangi radikal bebas pada sel dan mencegah kerusakan akibat oksidasi radikal bebas tersebut.

Antioksidan merupakan senyawa pemberi elektron (elektron donor) atau reduktan. Senyawa ini memiliki berat molekul kecil, tetapi mampu menginaktivasi berkembangnya reaksi oksidasi, dengan cara mencegah terbentuknya radikal bebas. Antioksidan juga merupakan senyawa yang dapat menghambat reaksi oksidasi, dengan mengikat radikal bebas dan molekul yang sangat reaktif sehingga kerusakan sel dapat dihambat. Antioksidan dapat berupa enzim (misalnya SOD, CAT dan GSPH), vitamin (misalnya vitamin E, C, A dan $\beta$-karoten) dan senyawa lain (misalnya flavonoid, albumin, bilirubin, seruloplasmin dan lain-lain). Antioksidan enzimatis merupakan sistem pertahanan utama (primer) terhadap kondisi stres oksidatif yang bekerja dengan cara mencegah terbentuknya senyawa radikal bebas. Disamping itu ada juga antioksidan nonenzimatis yang dapat berupa senyawa nutrisi maupun non-nutrisi. Kelompok antioksidan nonenzimatis ini disebut juga antioksidan sekuder karena dapat diperoleh dari asupan makanan seperti vitamin $A, C, E$ dan $\beta$-karoten.

Salah satu antioksidan nonenzimatis alami yang dapat dengan mudah diperoleh adalah buah tomat. Buah tomat banyak mengandung vitamin $\mathrm{C}$, vitamin $\mathrm{E}$ dan betakaroten serta senyawa fenolik. Buah tomat memilki kandungan antioksidan yang cukup tinggi. Buah tomat selain mengandung vitamin $\mathrm{C}$ juga mengandung lycopene atau sering disebut sebagai $\alpha$-carotene yaitu karotenoid pigmen merah terang yang banyak ditemukan dalam buat tomat dan buah-buahan lain yang berwarna merah. Lycopene merupakan jenis antioksidan kuat yang berfungsi mencegah kerusakan alami sel-sel tubuh. Kemampuannya mengendalikan radikal bebas 100 kali lebih efisien dari pada vitamin E atau 12.500 kali dari pada gluthation. Menurut Wirya (2000), pemberian kombinasi vitamin $\mathrm{C}$ dengan bioflavonoid dapat menghalangi dan menghentikan pembentukan superoksida dan hirogen peroksida, sehingga dapat mencegah terjadinya kerusakan jaringan akibat oksidan. 
Tomat merupakan sayuran yang kaya akan berbagai senyawa antioksidan seperti likopen, alfa-karoten, betakaroten, lutein, vitamin C, flavonoid, dan vitamin E Menurut Clinton (1998), lebih dari $80 \%$ asupan likopen penduduk Amerika Serikat berasal dari tomat. Tomat makanan yang selalu menarik dan lezat disajikan baik dalam keadaan mentah atau dimasak.

Tomat merupakan buah pangan yang saat ini telah dikonsumsi di seluruh penjuru dunia. Tomat mengandung lycopene, salah satu antioksidan alami yang sangat kuat ternyata terkandung di dalam buah tomat dengan kadar 30-100 ppm (Bombardelli, 1999).

Lycopenne memiliki kemampuan untuk mencegah penyakit kanker. Saat ini telah dikembangkan pula ekstrak buah tomat yang digunakan sebagai treatment tekanan darah tinggi. Selain digunakan sebagai sayur, tomat juga digunakan dalam seni kuliner, seperti tomato paste, tomato puree, tomato pie, gazpacho (Andalussia), pamb tomaquet (spanyol) dan pizza (Italy).

Adapun manfaat dari tomat bagi kesehatan tubuh adalah sebagai berikut: mengencerkan darah, menurunkan resiko katarak, penyakit jantung, dan stroke, mengurangi resiko kanker terutama kanker prostat, meningkatkan fungsi pencernaan dan meningkat sistem kekebalan tubuh, mengurangi gejala radang hati, menghilangkan kelelahan dan menambah nafsu makanm, membantu menjaga kesehatan organ hati, ginjal, dan mencegah kesulitan buang air besar. Tomat merupakan sayuran yang kaya akan berbagai senyawa antioksidan seperti likopen, alfa-karoten, beta-karoten, lutein, vitamin $\mathrm{C}$, flavonoid, dan vitamin

\section{METODE}

Disain penelitian ini, yaitu studi eksperimental menggunakan rancangan randomized pretest-posttest control group design. Subjek terdiri dari 32 orang yang terdiri dari 16 orang kelompok kontrol dan 16 orang kelompok diberi jus buah tomat. Kriteria inklusi sampel yang digunakan dalam penelitian ini harus memenuhi kriteria inklusi: ibu hamil trimester ketiga (2537 minggu), umur 20-35 tahun, $\mathrm{Hb} \geq 11$ gr \%, primigravida dan Multigravida, bersedia ikut dalam penelitian dibuktikan dengan penandatanganan informed consent.

Sedangan kriteria eksklusi, ibu hamil dengan penyakit seperti asma bronkhial, thyroid, hypertensi, penderita kelainan jantung, asma atau masalah paru-paru kronik, tiroid, dan kegemukan. Penelitian dilaksanakan di Klinik Bersalin Budi Indah Palembang pada bulan 3 Mei 2013. Pemeriksaan kadar antioksidan berupa Superoxide Dismutase (SOD) dilakukan di laboratorium Biokimia FK UI.

Teknik analisa data yang digunakan adalah uji parametrik untuk menganalisis menggunakan SPSS 20 untuk windows. Uji normalitas dengan Shapiro Wilk dengan $\alpha=0,05$. Analisis data perbedaan rata-rata kadar antioksidan sebelum dan sesudah pada kelompok diberi jus buah tomat dan kelompok tidak diberi jus buah tomat dengan menggunakan uji -t berpsangan dengan $\alpha=0,05$. Analisis data perbedaan rata-rata kadar antioksidan sebelum dan sesudah pada kelompok diberi jus buah tomat dan kelompok tidak diberi jus buah tomat dengan menggunakan uji $-\mathrm{t}$ berpsangan dengan $\alpha=0,05$.

Analisis komparabilitas; dilakukan terhadap nilai pre-test pemberian jus buah tomat dan tidak diberikan jus buah tomat menggunakan uji-t tidak 
berpasangan pada tingkat kemaknaan dengan $\alpha=0,05$. Analisis perbedaan rata-rata; dengan asumsi varian pada kedua kelompok equal maka perbedaan rata-rata antara hasil pengukuran SOD pada kelompok dengan pemberian jus buah tomat dengan kelompok tidak diberikan jus buah tomat yang ditentukan berdasarkan nilai post-test antara kedua kelompok tersebut dianalisis dengan uji-t tidak berpasangan pada tingkat kemaknaan $\alpha=0,05$.

\section{HASIL}

Pada penelitian melibatkan 32 orang ibu hamil dengan umur kehamilan 25-37 minggu. Subjek dibagi 2 menjadi kelompok, yaitu kelompok kontrol dan kelompok pemberian jus buah tomat (perlakuan), dimana kelompok kontrol terdiri dari 16 orang ibu hamil dan 16 orang kelompok diberi jus buah tomat (perlakuan). Pada penelitian ini subjek penelitian adalah ibu hamil trimester keIII.

Adapun karakteristik subjek penelitian meliputi : umur ibu hamil (tahun), usia kehamilan (minggu) graviditas/kehamilan (primipara \& multipara). Uji normalitas dari karakteristik subjek penelitian baik kelompok kontrol maupun pemberian jus buah tomat (perlakuan) tercantum pada tabel berikut ini:

Tabel1. Karakteristik Subjek Penelitian kelompok Kontrol dan Pemberian jus buah buah tomat

\begin{tabular}{|c|c|c|c|c|c|}
\hline No & Variabel & Rerata \pm SD & \multicolumn{2}{|c|}{$95 \%$ Confidence Interval } & p value ${ }^{*}$ \\
\hline \multirow[t]{4}{*}{1} & Kontrol & & Lower & upper & \\
\hline & Umur (tahun ) & $1,69, \pm 0,793$ & 1,26 & 2,11 & 0,854 \\
\hline & Usia kehamilan (minggu) & $1,44 \pm 5,12$ & 1,16 & 1,71 & 0,792 \\
\hline & Gravidas/Kehamilan ke & $1,63 \pm 0.885$ & 1,15 & 2,10 & 0,012 \\
\hline \multirow[t]{4}{*}{2} & Perlakuan & & & & \\
\hline & Umur & $1,75 \pm 0,856$ & 1,29 & 2,21 & 0,18 \\
\hline & Usia kehamilan (minggu) & $1,88 \pm 1,44$ & 1,49 & 2,26 & 0,960 \\
\hline & Gravidas/kehamilan ke & $1,75 \pm 0,683$ & 1,39 & 2,11 & 0,012 \\
\hline
\end{tabular}

*Uji normalitas dengan Shapiro Wilk dengan $\alpha=0,05$

Berdasarkan Tabel l di atas didapatkan bahwa tidak terdapat perbedaan yang bermakna $(p>0,05)$ untuk variabel umur dan usia kehamilan baik pada kelompok kontrol maupun perlakuan, hal ini berarti data umur dan usia kehamilan subjek penelitian berdistribusi normal. Sebaliknya untuk variabel graviditas datanya tidak berdistribusi normal $(p<0,05)$ hal ini dikarenakan peneliti membagi graviditas dalam dua kelompok yaitu primipara dan multipara. Peneliti tidak membatasi kriteria graviditas, sehingga kedua kelompok graviditas diambil sebagai subjek penelitian.

\begin{abstract}
Distribusi kadar SOD sebelum dan sesudah pemberian jus buah tomat Pada penelitian ini dilakukan pengukuran kadar SOD sebelum dan sesudah perlakuan, untuk melihat dampak pemberian jus buah tomat terhadap kadar SOD. Untuk menentukan apakah uji statistik yang digunakan adalah uji parametrik atau nonparametrtik dilakukan uji normalitas pada kedua variabel penelitian tersebut. Hasil uji normalitas kedua variabel penelitian disajikan pada tabel berikut.
\end{abstract}

Tabel 2. Kadar SOD Sebelum dan Sesudah Pemberian jus buah tomat (Perlakuan)

No Kelompok Kadar SOD (U/ml) p value*




\begin{tabular}{cccccc}
\hline & \multicolumn{1}{c}{$\begin{array}{c}\text { Sebelum } \\
\text { Rerata } \pm \text { SD }\end{array}$} & $\begin{array}{c}\text { Sesudah } \\
\text { Rerata } \pm \text { SD }\end{array}$ & Sebelum & Sesudah \\
& Kontrol & $311.91 \pm 130.930$ & $311.92 \pm 130.928$ & 0,136 & 0.136 \\
2 & Perlakuan & $408.385 \pm 139.05$ & $304.581 \pm 79.53$ & 0,006 & 0,42
\end{tabular}

*Uji normalitas dengan Shapiro Wilk dengan $\alpha=0,05$

Berdasarkan Tabel 2 di atas menunjukkan bahwa, hasil uji normalitas pada kelompok kontrol dan pemberian jus buah tomat (perlakuan) untuk kadar SOD sebelum dan sesudah pemberian jus buah buah (perlakuan) memilkik nilai $\mathrm{p}>0,05$ artinya kadar SOD pada kedua kelompok ini berdistribusi normal. Untuk itu uji statistik yang digunakan adalah uji-t berpasangan. Hasil uji-t berpasangan terdapat pada tabel berikut.

Tabel 3. Perbandingan Kadar SOD Sebelum dan Sesudah Pemberian jus buah tomat (Perlakuan)

\begin{tabular}{lcccc}
\hline No & Kelompok & \multicolumn{2}{c}{ Kadar SOD (U/ml) } & pvalue* \\
\hline & & Sebelum & Sesudah & \\
& & Rerata \pm SD & Rerata \pm SD & \\
1 & Kontrol & $311.91 \pm 130.930$ & $311.92 \pm 130.928$ & 0,250 \\
2 & Perlakuan & $408.39 \pm 139.05$ & $304.58 \pm 79.53$ & 0,003
\end{tabular}

*Uji t berpasangan dengan $\alpha=0,05$

Berdasarkan Tabel 3 di atas menunjukkan bahwa pada kelompok kontrol tidak terdapat perbedaan yang bermakna sebelum dan sesudah pemberian jus buah tomat (perlakuan) dengan $(p>0,05)$. Pada kelompok Pemberian jus buah tomat (perlakuan) terdapat perbedaan yang bermakna kadar SOD sebelum dan sesudah pemberian jus bauh tomat (perlakuan) $(\mathrm{p}<0,05) . \quad$ Selanjutnya untuk membandingkan kadar SOD antara kelompok kontrol dengan kelompok pemberian jus buah tomat (perlakuan) dilakukan uji -t tidak berpasangan. Hasil uji-t tidak berpasangan antara kedua kelompok tersebut ditampilkan pada tabel berikut.

\begin{tabular}{|c|c|c|c|c|}
\hline \multirow[t]{2}{*}{ No } & \multirow[t]{2}{*}{ Variabel } & \multicolumn{2}{|c|}{ Kadar SOD (U/L) } & \multirow[t]{2}{*}{ p value* } \\
\hline & & $\begin{array}{c}\text { Kontrol } \\
\text { Mean } \pm \text { SD }\end{array}$ & $\begin{array}{c}\text { Perlakuan } \\
\text { Mean } \pm \text { SD }\end{array}$ & \\
\hline 1 & Sebelum & $311.91 \pm 130.930$ & $408.39 \pm 139.05$ & 0,010 \\
\hline 2 & Sesudah & $311.92 \pm 130.928$ & $304.58 \pm 79.53$ & 0.849 \\
\hline
\end{tabular}

\section{*Uji t tidak berpasangan dengan $\alpha=0,05$}

Berdasarkan Tabel 4 di atas didapatkan bahwa rerata kadar SOD sebelum pada kelompok kontrol dibandingkan dengan kelompok pemberian jus buah tomat (perlakuan) terdapat perbedaan yang bermakna $(\mathrm{p}<0,05)$, sedangkan kadar SOD 
sesudah perlakuan pada kelompok kontrol dibandingkan dengan kelompok pemberian jus buah tomat (perlakuan)

\section{PEMBAHASAN}

Pada penelitian ini didapatkan hasil bahwa terdapat perbedaan yang bermakna antara kadar SOD setelah senam hamil dengan kadar SOD setelah pemberian jus buah tomat $(p<0,05)$. Setelah senam hamil didapatkan kadar SOD 408.39 \pm 139.05 $\mathrm{U} / \mathrm{ml}$, sedangkan setelah pemberian jus buah tomat didapatkan kadar SOD 304.58 $\pm 79.53 \mathrm{U} / \mathrm{ml}$. Menurut peneliti hal ini mengindikasikan bahwa senam hamil yang dilakukan dalam penelitian ini meningkatkan kadar radikal bebas sehingga kadar SOD setelah senam hamil terjadi peningkatan. Ketika melakukan aktifitas fisik konsumsi oksigen akan meningkat karena terjadi peningkatan metabolisme di dalam tubuh terutama oleh otot-otot yang berkontraksi sehinggga menyebabkan kebocoran elektron dari mitokondria yang akan menjadi ROS, peningkatan produksi ROS bersifat sangat reaktif terhadap sel atau komponen sel sekitarnya (Chevion, et al, 2003;Evan, 2000).

Hal yang sama juga dikemukakan oleh Clarkson and Thompson (2000), bahwa aktivitas olah raga akan meningkatkan kebutuhan oksigen melalui pernafsan untuk menghasilkan energi. Oksigen yang tersedia tidak seluruhnya terpakai oleh tubuh untuk menghasilkan energi, sisa oksigen inilah yang berjumlah $\pm 4-5 \%$ akan membentuk radikal bebas sehingga terbentuk reactive oxygen species (ROS) dan situasi ini memicu terjadinya peroksidasi asam-asam lemak tidak jenuh jamak (polyun-saturated fatty acid) dari membran sel maupun darah sehingga mempengaruhi fungsi sel dan bisa merusak kehidupan sel. Peningkatan ROS ini apabila tidak diimbangi dengan peningkatan kadar antioksidan dapat mengakibatkan terjadi peningkatan malondialdehide (MDA) yang merupakan indikator terjadnya stres oksidatif (Halliwell,1999). Dalam keadaan normal radikal bebas yang diproduksi oleh tubuh tidak terdapat perbedaan yang bermakna ( $p>0,05)$.

akan dinetralisir oleh antioksidan yang ada di dalam tubuh atau antioksidan endogen (Clarkson,2000). Superoxide Dismutase (SOD) merupakan salah satu enzim antioksidan endogen yang berguna sebagai sistem pertahanan terhadap senyawa ROS. Aktivitas enzim SOD memiliki peran penting dalam sistem pertahanan tubuh terutama terhadap ROS yang dapat menyebabkan stres oksidatif (Gur, 2003).

Dalam penelitian ini terjadi peningkatan kadar Superoxide Dismutase (SOD) setelah senam hamil, hal ini menunjukkan bahwa senam hamil mengakibatkan terjadinya peningkatan reactive oxydative stress (ROS). Adanya radikal bebas yang dihasilkan dalam tubuh dan terbentuknya ROS, sebenarnya merupakan proses fisiologis. Bila terjadi peningkatan radikal bebas, tubuh akan berusaha untuk mengatasi situasi ini dengan memproduksi sejumlah antioksidan (Clarkson and Thompson, 2000). Peningkatan antioksidan enzimatis seperti SOD merupakan keadaan yang bisa terjadi bila seseorang melakukan olah raga, termasuk wanita hamil. Peningkatan SOD diperlukan untuk mencegah kerusakan sel yang disebabkan oleh terbentuknya radikal bebas (Jasinevicius, 2009).

Hasil penelitian ini sejalan dengan hasil penelitian Wagey (2011) yang menyatakan bahwa terjadi peningkatan kadar antioksidan enzimmatik, SOD, pada ibu hamil yang mendapatkan senam hamil sejak usia kehamilan memasuki usia 20 mingggu. Penelitian yang dilakukan oleh Velez (2012) juga mendapatkan terjadi peningkatan kadar antioksidan pada ibu primigravida dengan usia kehamilan 16-20 minggu yang melakukan aktifitas fisik aerobik selama 60 menit dengan frekuensi tiga kali per mingggu. Begitu juga hasil penelitan yang di dapat oleh Yeo and Davidge (2001) didapatkan bahwa aktivitas fisik yang dilakukan secara reguler meningkatkan 
kadar enzim antioksidan pada ibu hamil. Kondisi ini mengakibatkan terjadinya penurunan stres oksidatif, dimana stres oksidatif tersebut merupakan faktor pencetus terjadinya preeklampsia. Aktifitas fisik meningkatkan ekpresi dan aktifitas SOD. Pada ibu hamil yang melakukan aktivitas fisik kemungkinan untuk terjadinya preeklampsia sangat rendah.

Pada penelitian ini setelah senam hamil dilakukan pemberian jus buah tomat yang merupakan antioksidan nonenzimatis. Pemberian jus buah tomat ini bertujuan untuk meningkatkan kadar antioksidan pada ibu hamil. Menurut Clarkson (1995) meskipun tubuh secara alami dapat mengatasi peningkatan radikal bebas tetapi pada kondisi tertentu seperti pada latihan fisik yang relatif berat, antioksidan endogen tidak mencukupi sehingga tubuh memerlukan antioksidan dari luar.

Kadar SOD setelah pemberian jus buah tomat pada penelitian ini terjadi penurunan, kadar SOD sebelum pemberian jus buah tomat $408.39 \pm 139.05 \mathrm{U} / \mathrm{ml}$, sedangkan sesudah pemberian jus buah tomat $304.58 \pm 79.53 \mathrm{U} / \mathrm{ml}$. Menurut peneliti penurunan ini dikarenakan subjek penelitian dalam kondisi istirahat, walaupun senam hamil mengakibatkan peningkatan radikal bebas akan tetapi kemungkinan besar enzim SOD sudah beraktivitas untuk menetralisir radikal bebas pada saat senam hamil berlangsung. Selain itu menurunnya kadar SOD menunjukkan bahwa tubuh sudah tidak banyak menggunakan SOD untuk menangkal radikal bebas.

Pada penelitian ini antioksidan yang digunakan antioksidan nonenzimatik yaitu jus buah tomat. Buah tomat mengandung zat antioksidan yang disebut likopen. Likopen merupakan senyawa potensial untuk antikanker (Giovannuci, 2007 cit Wahyuni, 2008) dan mempunyai aktivitas antioksidan dua kali lebih kuat dari $\beta$ karoten dan sepuluh kali lebih kuat dari vitamin E (Didinkaem, 2006). Tomat memiliki kemampuan antioksidan yang dapat memadamkan radikal bebas, tomat juga dapat memberikan proteksi terhadap kerusakan oksidatif yang secara potensial mencegah mutasi pada fase inisiasi dan progresi dari kanker.

Menurut Giovannucci (1991), likopen merupakan salah satu kandungan kimia yang paling banyak dalam tomat, dalam 100 gr tomat rata-rata mengandung likopen sebanyak 3-5 mg. Kemampuan mengendalikan radikal bebas 100 kali lebih efisien dari pada vitamin E atau $12500 \mathrm{kali}$ dari pada gluthation. Levy, et al (1995) menyebutkan bahwa likopen mampu menghambat pertumbuhan kanker endometrial, kanker payudara dan kanker paru-paru pada kultur sel dengan aktivitas yang lebih tinggi dibandingkan dengan $\alpha$ dan $\beta$-karoten. Likopen juga ditemukan mampu menginaktifkan hidrogen peroksida dan nitrogen peroksida (Bohm,et al, 1995). Menurut Sunarmani dan Tati (2008), jumlah likopen dalam jus tomat bisa mencapai lima kali lebih banyak dari pada tomat segar. Tomat yang dimasak atau dihancurkan dapat mengeluarkan likopen lebih banyak, sehingga mudah diserap tubuh.

\section{SIMPULAN}

1. Rata-rata kadar SOD sebelum dan sesudah pemberian jus buah tomat pada ibu hamil yang melakukan senam hamil terdapat perbedaan yang bermakna $(p<0,005)$.

2. Rara-rata kadar SOD pada kelompok kontrol yaitu ibu hamil yang tidak melakukan senam hamil tidak terdapata perbedaan yang bermakna $(\mathrm{p}>0,005)$

3. Rata-rata kadar SOD pada kelompok kontrol dibandingkan dengan kelompok perlakuan terdapat perbedaan yang bermakna $(p<0,005$

\section{REFERENSI}

Abdullah,A and Abdullah, F. 2004. Exercise and Pregnancy, Middle East Journal Of Family Medicine. Vol.2. 
Ahuja, K. D. K., El Ashton, M. J., Ball., 2003. Effect of A High Monounsatturated Tomato-rich Diet on Serum of Licopene. Eu J. of Chin Nutr 57; 832842

Arab, L and S. Steck. 2000. Lycopene and Cardiovaskular Disease. American Journal Of Cincal Nutrition. 71:16911695

Argawal, A. Gupta, S and Sharma, R.K. 2005. Role Of Oxidative Stress in Female Reproduction. Reprod Biol Endecrinol.3: p. 28-29.

Aruoma, O. I. 1999. Free Radicals, Antioksidant and International Nutrition : Review Article. Asi Facific J. Clin Nutr 8 (53-63)

Bohm, V., N. L. Puspitasari-Nienaber, M. G. Ferruzi, dan S. J. Schwartz. 2002. Trolox equivalent antioxidant capacity of different geometrical isomer of-carotene, carotene, lycopene, and zeaxanthin. J. Agric. Food Chem.50: 221-226.

Brankston, G.N, Mitchel, B.F, Ryan, Edmon, A and Okun, N.B, 2004. Rsistance exercises decrease the need for insulin in overweight womwn with gestational diabetes melitus, Am J Obstet Gynecol 190. Issue 1.p.188-193 Casanueva, R and Viteri, F. R, 2003. Iron and Oxidative stress in pregnancy. J Nurt133:p1700S-1708S

Clarkson, P. M andn Thompson, H. S. 2000. Antioxidants: what role do they olay in physical activity and health.
Departemen Kesehatan R. I. 2001. Daftar Komposisi Bahan Makanan. Direktorat

Gizi. Departemen Kesehatan R. I. Bhratara. Jakarta.

Halliwell, B., Gutteridge, J. Free Radical in Biology and Medicine. Oxford: Oxford Science Publicatio. 1999; 442-267

Jauniaux, E., Ponston, L., and Bonston G.J. 2006 Placental-related Sieased of pregnancy:involvement of oxidative stress anf implications in human evolution Hum Reprod.12 (6): 747755

Klaüi, H. dan Bauernfeind, J. C. 1981. Carotenoids as Food Colors. Di Dalam: Bauernfeind, J. C. (ed.). Carotenoid as Colorants and Vitamin A Precursors. Academic Press. New York.

Thompson, K. A., M. R Marshall, C. A. Sims, S. A. Sargent, dan J. W. Scott. 2000. Cultivar, maturity, and heat treatment on lycopene content in tomatoes. Journal of Food Sci. Vol. 65. No. 5: 791795.

Tsang,G. 2005. Lycopene in Tomatoes and Prostate Cancer. http//www.healthcastle.com

Wirya, I. 2002 Pemberian Suplemen Kompleks Antioksidan pada Pelari Sprint 200 meter untuk Menurunkan Kadar Laktat Darah. Medika (52): 6-10 